\title{
La comunidad laboral del ingenio Bella Vista: la resignificación de la experiencia obrera en los inicios del peronismo*
}

\begin{abstract}
Resumen
El objetivo del presente artículo es analizar la experiencia obrera de la comunidad del ingenio Bella Vista ubicada en la provincia de Tucumán (región noroeste de Argentina). En este procuramos comprender cómo las vivencias cotidianas de los trabajadores y la dinámica del pueblo azucarero fueron resignificadas por la irrupción del peronismo, particularmente por el avance de la organización sindical y del poder obrero, procesos inescindibles del reposicionamiento que asumió el Estado en materia laboral. También, argumentamos que la creación y el afianzamiento del sindicato fueron acciones que interpelaron prácticas del paternalismo empresarial, coadyuvaron a la promoción de formas de sociabilidad ajenas a la patronal y desafiaron las tradicionales atribuciones de los industriales. De ese modo, recuperamos las particularidades de un conjunto de trabajadores - muchas veces homogeneizados bajo el paraguas de su condición azucarera y pertenencia sindical- y avanzamos en una perspectiva de análisis micro que ocupa un lugar tangencial en la historiografía sobre dicho período.
\end{abstract}

Palabras clave: Tucumán, comunidad laboral, sindicato, industria azucarera, peronismo.

Referencia para citar este artículo: LICHTMAJER, Leandro; GUTIÉRREZ, Florencia y SANTOS LEPERA, Lucía (2016). "La comunidad laboral del ingenio Bella Vista: la resignificación de la experiencia obrera en los inicios del peronismo". En Anuario de Historia Regional y de las Fronteras. 21 (1). pp. 213-236.

Fecha de recepción: 20/02/2015

Fecha de aceptación: 26/06/2015

Leandro Lichtmajer: Doctor en Humanidades (área historia) y Licenciado en Historia, Facultad de Filosofía y Letras, Universidad Nacional de Tucumán. Investigador asistente (Consejo Nacional de Investigaciones Científicas y Técnicas). Auxiliar docente (Cátedra de Historia Argentina -Curso Especial-, Facultad de Filosofía y Letras, Universidad Nacional de Tucumán). Correo electrónico: leandrolichtmajer@gmail.com.

Florencia Gutiérrez: Doctora y Maestra en Historia, El Colegio de México. Licenciada en Historia, Facultad de Filosofía y Letras, Universidad Nacional de Tucumán. Correo electrónico: florenciagutierrezb@ yahoo.com.

Lucía Santos Lepera: Doctora en Humanidades (área historia) y Licenciada en Historia, Facultad de Filosofía y Letras, Universidad Nacional de Tucumán. Becaria posdoctoral (Consejo Nacional de Investigaciones Científicas y Técnicas). Jefe de trabajos prácticos (Cátedra de Historia General de la Cultura, Facultad de Artes, Universidad Nacional de Tucumán). Correo electrónico: luciasantoslepera@gmail.com.

\footnotetext{
* Artículo de reflexión, producto de los proyectos de investigación Actores, Estado y políticas en Tucumán, 1880-1955 y Sindicalismo, política y Estado. Tucumán, 1943-1955 financiados por la Universidad Nacional de Tucumán. Una versión modificada del artículo fue presentada como ponencia en el XII Congreso Nacional de Estudios del Trabajo realizado en la ciudad de Buenos Aires entre el 5 y el 7 de agosto de 2015. Agradecemos las sugerencias y los comentarios de Gustavo Contreras a una versión preliminar de este trabajo. Por su parte, Alejandra Landaburu y Manuel Valeros nos facilitaron documentos de gran utilidad.
} 


\title{
Working Community at the Bella Vista Sugar Mills: Resignification of the Working Experience at the Beginning of Peronism
}

\begin{abstract}
The objective of this article is to analyze the working class experience at the Bella Vista sugar mill community located at the Tucuman province (Argentinean northwest). We focused on understanding how daily life of workers and the dynamics of this sugar-producing community were resignified by the arrival of Peronism, particularly the advancement of unionism and the power of workers, inseparable processes accompanying the repositioning of the State in labor matters. We believe that the creation and strengthening of unions interfered with business paternalism practices, contributed to the promotion of sociability forms different from patron-related issues, and represented a challenge for the traditional power of industrialists. The reduction of the analytical scale in this work facilitates the understanding of relatively unexplored aspects of daily life of sugar mill workers at the beginning of peronism. We, then, recover the characteristics of a set of workers that have been frequently homogenized due to their relation with the sugar mill and their common ground as union members. We advanced in a microanalysis perspective that is ranked in a tangential place within the historiography of this period.
\end{abstract}

Keywords: Tucumán, working community, unions, sugar mill industry, peronism.

\section{A comunidade laboral do engenho Bella Vista: a ressignificação da experiência trabalhadora no início do peronismo}

\begin{abstract}
Resumo
O objetivo do presente artigo é analisar a experiência trabalhista da comunidade do engenho Bella Vista, localizada na província de Tucumán (região noroeste da Argentina). Procuramos compreender como as vivencias cotidianas dos trabalhadores e a dinâmica do povo açucareiro foram resignificadas pela irrupção do peronismo, particularmente pelo avanço da organização sindical e do poder operário, processo inseparável do reposicionamento que assumiu o Estado em questões trabalhistas. Também, argumentamos que a criação e a consolidação do sindicato foram ações que interpelaram práticas do paternalismo empresarial, estimularam a promoção de formas de sociabilidade diferentes do empregador tradicional e desafiaram as atribuições tradicionais dos industriais. Dessa maneira, recuperamos as particularidades de um conjunto de trabalhadores - muitas vezes homogeneizados sob a égide de sua condição açucareira e pertinência sindicale avançamos em uma perspectiva de microanálise que ocupa um lugar tangencial na histografia do periodo citado.
\end{abstract}

Palavras-chave: Tucumán, comunidade trabalhadora, sindicato, indústria açucareira, peronismo. 


\section{Introducción}

En el último cuarto del siglo XX la historiografía latinoamericana revitalizó el estudio de los mundos del trabajo desde múltiples perspectivas. Una de las aristas de esta renovación fue la reducción de la escala de observación: estrategia metodológica que al volver la mirada sobre comunidades laborales particulares, horadó la visión de los trabajadores como un sujeto homogéneo ${ }^{1}$. Revisitar el universo laboral haciendo foco en una fábrica, en un taller, en un pozo petrolero o en un pueblo azucarero, supone recuperar experiencias que privilegian su rama productiva y sus organizaciones gremiales y que son consideradas - muchas veces-invisibilizadas en los estudios que abordaron a los obreros. En tal sentido, la manera en que el género y la sexualidad gravitaron en la división del trabajo; las complejas formas de consenso, de resistencia y de negociación tramitadas en los espacios laborales o la incidencia de la etnicidad en la formación de la clase social fueron algunas de las expresiones de este giro historiográfico.

La producción histórica argentina no escapó a las miradas universalizadoras de los trabajadores, pero tampoco fue esquiva a las renovadas perspectivas de análisis que se hicieron presentes desde el retorno de la democracia en 1983. Uno de los ejes analíticos que modeló este derrotero fue, sin duda, el vínculo entre la clase trabajadora y el peronismo, piedra de toque de la historia contemporánea argentina. Desde la Secretaría de Trabajo y Previsión (STyP) ${ }^{2}$ y luego, como presidente de la nación, Juan Domingo Perón vehiculizó un proceso inédito de reconocimiento e integración social y política de la clase trabajadora ${ }^{3}$. La gravitación de esta transformación fue mensurable a partir del exponencial crecimiento sindical y del avance de derechos sociales, pero también de factores menos tangibles y difíciles de cuantificar como “[...] el orgullo, el respeto propio y la dignidad" vivenciados por los trabajadores a lo largo de dicha etapa ${ }^{4}$.

\footnotetext{
${ }^{1}$ Lobato, Mirta. La vida en las fábricas. Trabajo, protesta y política en una comunidad obrera, Berisso (1904-1970) (Buenos Aires, Prometeo, 2004), p. 25. Para el espacio latinoamericano remitimos a Klubock, Thomas. Contested Communities. Class, Gender and Politics in Chile's El Teniente Cooper Mine, 1904-1951. (Durham: Duke University Press, 1998); Negro, Antonio Luigi. “Zé Brasil foi ser peão: sobre a dignidade do trabalhador não qualificado na fábrica automobilística”, en Batalha, Claudio; Teixeira Da Silva, Fernando y Fortes, Alexandre (orgs.), Culturas de Classe (Campinas: UNICAMP, 2009), pp. 403-438.

${ }^{2}$ La STyP fue creada en noviembre de 1943 por un decreto del presidente de facto Pedro P. Ramírez. Al frente de dicho organismo asumió el general Juan Domingo Perón. En la STyP se absorbieron las dependencias nacionales y provinciales dedicadas al arbitraje en conflictos entre el capital y el trabajo, entre las que se destacaba el Departamento Nacional del Trabajo, creado en 1907. Sus funciones eran: arbitrar en los conflictos obrero-patronales, confeccionar leyes laborales y vigilar su cumplimiento, reglamentar el funcionamiento de las asociaciones profesionales y preparar el terreno para el desarrollo de políticas sociales. En las provincias los Departamentos de Trabajo fueron convertidos en Delegaciones Regionales de la Secretaría de Trabajo y Previsión (DRSTyP). Lobato, Mirta y Suriano, Juan. La sociedad del trabajo. Las instituciones laborales en Argentina (1900-1955) (Buenos Aires: Edhasa, 2014).

${ }^{3}$ En este contexto de preocupaciones, remitimos a las investigaciones de Doyon, Louise. Perón y los trabajadores. Los orígenes del sindicalismo peronista, 1943-1955 (Buenos Aires: Siglo Veintiuno, 2006); James, Daniel. Resistencia e integración. El peronismo y la clase trabajadora argentina (1946-1976) (Buenos Aires: Sudamericana, 1990).

${ }^{4}$ James, Daniel. Resistencia e integración... Op. Cit., p. 40.
} 
Luego del golpe de Estado de 1955 que derrocó a Perón, diversas interpretaciones procuraron explicar la génesis del peronismo, particularmente, el papel de los obreros en dicho movimiento político. Estas propuestas tuvieron como denominadores comunes una fuerte impronta sociológica: la adscripción a la ciudad y a la provincia de Buenos Aires como unidades de análisis y el foco en los efectos del proceso de industrialización como objeto primordial. Esta opción -fructífera en muchos aspectos- obturó la posibilidad de pensar las múltiples aristas y solapamientos de la experiencia obrera y descuidó el análisis de las dinámicas regionales. No obstante, en las últimas décadas este corpus historiográfico comenzó a reformularse a partir de estudios impulsados desde las provincias. Estos "[...] aportes extracéntricos"5 permitieron repensar los orígenes del peronismo en escenarios que, en términos de trayectorias políticas y laborales, poco tenían que ver con el abigarrado cordón industrial bonaerense. El estudio de la sindicalización de los trabajadores azucareros del noroeste o de los vitivinícolas de la región de Cuyo, por citar solo dos ejemplos, complejizaron las matrices interpretativas del peronismo ${ }^{6}$.

Sin embargo, uno de los desafíos de este campo es revisitar la experiencia obrera a partir de una escala de análisis micro que privilegie la mirada sobre las comunidades laborales. A pesar de los fructíferos resultados que reportó dicho enfoque para otros períodos de estudio, esta opción no fue asumida como propia por los investigadores del mundo del trabajo durante el primer peronismo.

En este contexto de preocupaciones, el presente artículo se focaliza en la comunidad laboral del ingenio Bella Vista, importante establecimiento fabril ubicado en la provincia de Tucumán (región noroeste de Argentina). Procuramos comprender cómo las vivencias cotidianas y la dinámica del pueblo azucarero fueron resignificadas por la irrupción del peronismo, particularmente por el avance de la organización sindical y el poder obrero, proceso inescindible del reposicionamiento que asumió el Estado en materia laboral y del histórico entramado socio-laboral bellavisteño. En ese sentido, nuestra hipótesis es que la creación y el progresivo afianzamiento del sindicato de base interpelaron prácticas del paternalismo empresarial, coadyuvaron a la promoción de formas de sociabilidad ajenas a la patronal y desafiaron las tradicionales atribuciones de los industriales. Es a partir de esto como los obreros resignificaron su experiencia de clase, valiéndose de la trayectoria en materia laboral y organizativa, y capitalizando el respaldo brindado por las agencias estatales.

Analizar las implicancias de este juego de desafíos y de empoderamientos supone recuperar aspectos nodales de la experiencia obrera en los primeros años peronistas. En efecto, los giros y nuevos sentidos otorgados a su cotidianeidad, la forma en que capitalizaron tradiciones laborales y organizativas previas, y la manera en que resignificaron el sentido de lo justo en su comunidad configuraron un conjunto de

\footnotetext{
${ }^{5}$ Macor, Darío y Tcach, César. La invención del peronismo en el interior del país (Santa Fe: Universidad Nacional del Litoral Editora, 2003), p. 21.

${ }^{6}$ Rubinstein, Gustavo. Los sindicatos azucareros en los orígenes del peronismo tucumano (Tucumán: Universidad Nacional de Tucumán, 2006); Garzón Rogé, Mariana. El peronismo en la primera hora (Mendoza: Editorial de la Universidad Nacional de Cuyo, 2014).
} 
prácticas que les permitió a la patronal cuestionarse y modificar su constitución como actores colectivos. En tal sentido, el horizonte teórico de este artículo se inscribe en la sugerente propuesta thompsoniana -que subrayó la importancia de describir a "[...] las personas relacionándose unas con otras en el transcurso del tiempo, el modo en que adquieren conciencia de sus relaciones, se separan, se unen, entran en conflicto, forman instituciones y transmiten valores en términos de clase" ${ }^{\text {7- }}$.

\section{La configuración de la comunidad laboral bellavisteña: jerarquías y desigualdades}

En el último tercio del siglo XIX la región del noroeste argentino fue el epicentro de una sensible transformación socio-económica sustentada en el cultivo e industrialización en gran escala de la caña de azúcar. Este nuevo complejo productivo articuló a las provincias norteñas con el exitoso modelo agroexportador argentino y las insertó como proveedoras de azúcar para un mercado interno que se expandía al ritmo del proceso inmigratorio y el desarrollo de la región pampeana. Tucumán fue uno de los centros neurálgicos del despegue azucarero y en su piedemonte se configuró un denso cordón agroindustrial que en 1890 contabilizaba 35 ingenios de diversa escala y capacidad productiva. La élite, constituida por "[...] antiguas familias con tradición en actividades comerciales y manufactureras" e inmigrantes europeos, promovió la emergencia de este complejo y contó con el apoyo del Estado nacional que mediante exenciones impositivas, créditos y medidas arancelarias proteccionistas alentó el desarrollo agroindustrial ${ }^{8}$. Un actor clave de este proceso fue el ferrocarril, el cual con su llegada a Tucumán en 1876 dinamizó la fase de comercialización y abastecimiento del mercado interno.

El ingenio Bella Vista, fundado en 1882 por los inmigrantes españoles José y Manuel García Fernández, fue una nítida expresión del auge azucarero. La fábrica, pionera en la incorporación de maquinaria moderna, se afincó en un paraje denominado Los Tres Bajos, 25 kilómetros al sudeste de San Miguel de Tucumán (capital provincial). $\mathrm{Su}$ ubicación le permitió contar con una privilegiada conexión con el Ferrocarril Central Córdoba, el cual atravesó “[...] las tierras del ingenio en toda su extensión”, y le permitió potenciar su comunicación con la región pampeana9. De esta manera, el ingenio ocupó velozmente el centro de la escena productiva de la provincia. En la década de 1910 sus edificaciones abarcaban un radio de 10.000 metros cuadrados y su producción lo posicionaba como el segundo establecimiento más importante de Tucumán, lugar que mantenía en la década de 1940.

\footnotetext{
${ }^{7}$ Thompson, Edward Palmer. "Folklore, antropología e historia social", en Thompson, Edward Palmer. Las peculiaridades de lo inglés y otros ensayos (Valencia: Centro Francisco Tomás y Valiente Universidad Nacional de Educación a Distancia Alzira-Valencia y Fundación Instituto de Historia Social, 2002), p. 163.

${ }^{8}$ Campi, Daniel. "Economía y sociedad en las provincias del norte", en Lobato, Mirta, et al. El progreso, la modernización y sus límites 1880-1916 (Buenos Aires: Sudamericana, 2000), p. 75.

${ }_{9}^{9}$ Padilla, Vicente. El norte argentino. Historia política-administrativa, social, comercial e industrial de las provincias de Tucumán, Salta, Jujuy, Santiago del Estero y Catamarca (Buenos Aires: Establecimiento gráfico Ferrari Hermanos, 1922), p. 301.
} 
El ingenio era el vértice generador y organizador de los pueblos azucareros, estos últimos como espacios privados que en ocasiones estaban cercados perimetralmente. La comunidad laboral reconocía en la fábrica su epicentro, “[...] directa o indirectamente todos estaban relacionados con el ingenio, única fuente de trabajo"10. Esto trasladaba el escalafón laboral a la vida cotidiana, lo que formó una "[...] sociedad de clases donde arriba estaba el administrador, luego los jefes jerárquicos, los empleados administrativos, los obreros fabriles y los peones de surco, que trabajaban los cañaverales, los de abajo" ${ }^{11}$. Esta configuración socio-laboral culminaba con los obreros temporarios, quienes llegaban de las provincias vecinas para la época de cosecha (zafra) que se extendía entre mayo y principios de octubre.

Estas desigualdades se proyectaron en la particular conformación de los pueblos azucareros, cuya fisonomía condensó el universo de jerarquías y de desigualdades sociales. El núcleo de la comunidad era el ingenio y el chalet de sus propietarios, y la distancia o proximidad que el resto de las viviendas tenían con estos referentes del poder socio-económico proyectaban el estatus social de sus habitantes. Las viviendas “[...] destinadas a los pocos empleados jerárquicos y técnicos se ubicaban pegadas o frente de las fábricas, luego las de los empleados administrativos, más alejadas la de los obreros permanentes y, luego de éstas, los pabellones o conventillos destinados a los trabajadores temporarios" $" 12$. Esta diagramación espacial era refrendada por los materiales, la calidad y el diseño utilizado en la construcción de las distintas viviendas ${ }^{13}$. La comunidad bellavisteña no escapó a esta contrastante realidad. El chalet, de formas y de perfiles ligados al renacimiento español, reflejaba el estilo de vida burgués que cultivaban los propietarios, los administradores y el personal jerárquico. Los jardines de invierno, los parques, las salas de juego y el suntuoso mobiliario eran expresiones de la refinada cotidianeidad de estos referentes del poder azucarero. El Bella Vista, como muchas otras fábricas, contó con una cancha de tenis, deporte practicado únicamente por los dueños y el personal jerárquico y administrativo.

En términos de estructura laboral, en los ingenios predominaba un organigrama piramidal centralizado - “[...] todas las funciones de coordinación y de control fluían de forma ascendente hacia la cabeza del establecimiento"- y representado por el administrador, quien contaba con la colaboración de mayordomos, de los jefes de fábrica y cultivo, de los capataces, de los empleados, etcétera ${ }^{14}$. Estos actores encarnaban la mirada e intereses de la patronal y eran considerados por los industriales

\footnotetext{
${ }^{10}$ Mercado, Lucía. El Gallo Negro. Vida, pasión y muerte de un ingenio azucarero (Tucumán: Producciones Gráficas, 1999), p. 16.

${ }^{11}$ Ibid.

12 Campi, Daniel. "Contrastes cotidianos. Los ingenios del norte argentino como complejos socioculturales, 1870-1930”, en Varia Historia, vol. XXV, n. ${ }^{\circ} 41$, Belo Horizonte, Universidade Federal de Minas Gerais, 2009, p. 254.

${ }_{13}$ Paterlini de Koch, Olga. Pueblos azucareros de Tucumán (Tucumán: Universidad Nacional de Tucumán, 1987).

${ }^{14}$ Moyano, Daniel. Firmas familiares, empresariado e industria azucarera en Tucumán, 1895-1945, (Tesis doctoral), Facultad de Filosofía y Letras, Universidad Nacional de Tucumán, 2011, p. 98.
} 
como sus "[...] más estrechos colaboradores", pues se encargaban de supervisar los procesos laborales, de controlar los ritmos productivos y de preservar el orden social de la comunidad ${ }^{15}$. La nómina de administradores del ingenio Bella Vista reflejaba su cercanía con los propietarios y era refrendada, en algunos casos, por vínculos de parentesco ${ }^{16}$.

La pirámide laboral se completaba con el nutrido y heterogéneo colectivo obrero que se escindía en dos: los trabajadores permanentes, de fábrica o surco, y los temporarios, quienes llegaban para la zafra. Los primeros accedían a una vivienda, cuya construcción y calidad variaba según los ingenios y podía ubicarse en el predio de la fábrica o en las colonias agrícolas lindantes. Al interior de este conjunto obrero era posible distinguir jerarquías sustentadas en las prácticas y los saberes que definían los oficios. Así, desde los orígenes de la agroindustria la particular cualificación de los maestros de azúcar y de los mecánicos convirtió a dichos sujetos en actores destacados de la cadena productiva y los ubicó por encima de la variada y compleja trama de ocupaciones (herreros, calderos, tractoristas y capataces, entre otros). Consecuentemente, los niveles de especialización generaron diferencias proyectadas en términos salariales (pago mensual), acceso a ciertos beneficios y espacios asociativos propios.

El extremo inferior del conjunto de obreros estables estaba conformado por los peones de surco, quienes vivían en las colonias agrícolas. En el caso del Bella Vista, estos no solo se dedicaban al cultivo de la caña de azúcar -Los García Fernández promovieron la producción de arroz, girasol, papa y maíz como una alternativa para revertir el monocultivo azucarero y ampliar la oferta de trabajo en los períodos de interzafra-. La incidencia de las colonias variaba según los pueblos; en Bella Vista, por ejemplo, los trabajadores agrícolas fueron un actor numéricamente importante. A principios de los cuarenta, en época de cosecha el pueblo sumaba un total de 4.200 trabajadores de fábrica y surco. Sin embargo, el contraste cuantitativo entre los distintos segmentos laborales era pronunciado. Por tanto, entre los obreros permanentes que alcanzaban un total de 2.200, la distribución era la siguiente: 1.700 de surco y 500 de fábrica ${ }^{17}$. El universo laboral se complementaba con los trabajadores temporarios que llegaban para la época de cosecha con sus familias desde las provincias limítrofes, especialmente Catamarca y Santiago del Estero. Desde fines del siglo XIX, la relación contractual se entablaba con el varón de la familia, aunque las mujeres y los niños colaboraban en la hachada, pelada y cargada de la caña, trabajo pagado a destajo. La gravitación de los obreros temporarios en la configuración del mercado laboral fue sustantiva y constituyó el eslabón más débil de la cadena productiva, el más precarizado y el más vulnerable.

\footnotetext{
${ }^{15}$ Ibid.

${ }^{16}$ Tales fueron los casos de Manuel Andrade, José Boucau, Felipe Boucau y Emilio Boucau (cuñados de Manuel García Fernández), Manuel García Fernández (hijo), Conrado Martínez Pastur (primo hermano de Manuel García Fernández -hijo-). Valeros, Manuel y Salazar, Antonio (comps.). Notas sobre la historia de Bella Vista (Tucumán: Universidad Nacional de Tucumán), p. 57.

17 "Ingenio y Refinería Bella Vista", La Nación, Buenos Aires, enero 28 de 1945, p. 6.
} 


\section{Tradición paternalista, coacción empresarial y experiencias obreras}

Desde la fundación del ingenio, la mirada y los intereses de la patronal hacia la comunidad laboral de Bella Vista se ubicaron en la intersección entre el paternalismo y la coacción. Como contrapunto, el conjunto obrero desplegó formas de resistencia, de solidaridad y de sociabilidad que fueron definiendo su experiencia de clase y la dinámica del pueblo. El Centro Azucarero Argentino (CAA), corporación que nucleaba a los industriales, señaló en 1943 que Bella Vista fue una de las primeras fábricas que se ocupó de mejorar la atención de los obreros ${ }^{18}$. Dicha afirmación recuperaba un ideario forjado desde principios del siglo XX por observadores propios y ajenos al establecimiento y que atribuía a García Fernández un singular esmero a la hora de brindar servicios a los trabajadores ${ }^{19}$.

En términos de vivienda, la temprana construcción de casas de material y las prestaciones para los obreros estables (surtidores de agua corriente, piletas de lavar, resumideros y luz eléctrica) convirtieron a la fábrica en referente del paternalismo empresarial $^{20}$.

En la esfera educacional, en 1895 se fundó la Escuela Ingenio Bella Vista destinada a los hijos de los trabajadores permanentes, emprendimiento que progresivamente se multiplicó por las colonias, y se complementó con una escuela de manualidades para niñas. El establecimiento también promovió la asistencia médica al fundar en 1916 el hospital San Luis, el cual disponía de una veintena de camas destinadas a la internación, suministraba gratuitamente medicamentos para el personal y contaba con una enfermera y una partera para la atención de las mujeres de los obreros ${ }^{21}$. Por otra parte, también se impulsó la entrega de la Gota de Leche ${ }^{22}$, la instalación de una olla infantil y una cocina popular, estas últimas funcionaban durante los meses de la interzafra, repartiendo raciones diarias de comida; y la implementación de un sistema de jubilaciones obreras y de pensiones para las viudas de los trabajadores. Todas estas actividades fueron prácticas que alimentaron la figura del buen patrón.

Sin embargo, los propietarios del ingenio Bella Vista, a tono con el resto del empresariado azucarero, fueron reticentes a convertir estos beneficios en derechos y reservaron la decisión de asignarlos a partir de un criterio discrecional, rechazando

\footnotetext{
${ }^{18}$ Centro Azucarero Argentino. Asistencia social en la industria azucarera (Buenos Aires: Establecimiento Gráfico Ferrari Hermanos, 1943), p. 9.

${ }^{19}$ Landaburu, Alejandra. Los empresarios azucareros y la cuestión social. Tucumán, 1904-1930, (Tesis doctoral), Universidad Nacional de Tucumán, 2014, p. 20.

${ }^{20}$ Ibid., p. 9.

${ }^{21}$ Padilla, Vicente. El norte... Op. Cit., pp. 301-309.

${ }^{22}$ La Gota de Leche fue una institución creada en 1894 en Francia con el fin de remediar los problemas de desnutrición y de alta mortalidad infantil de los sectores populares. Se introdujo en Tucumán en 1912 de la mano del empresario azucarero y filántropo Alfredo Guzmán, propietario del ingenio Concepción. Landaburu, Alejandra. Los empresarios... Op. Cit., p. 27.
} 
todo proyecto legislativo que los tornara en obligaciones ${ }^{23}$. Esta postura que procuraba sujetar las relaciones entre el capital y el trabajo a la esfera privada, postergó el mejoramiento global de la situación obrera y configuró un universo que, en términos de condiciones laborales, fue precario y sumamente heterogéneo.

La acción social de los industriales respondía a una visión particular de su obligación como patrones, que implicaba no sólo una dimensión económica, sino también una moral y una religiosa. Las prácticas paternalistas estaban imbuidas de un tinte religioso que ubicaba a García Fernández y a su familia en línea con el catolicismo social, corriente de gran influencia en un sector del empresariado azucarero tucumano. Desde esta perspectiva, los patrones se erigían en dispensadores de beneficios que esperaban ser retribuidos con muestras de obediencia y fidelidad obrera ${ }^{24}$. Esa relación paternalista que apelaba a una esencia moral, basaba su éxito en la adhesión de los obreros a los valores que les eran propuestos e impuestos ${ }^{25}$. La filantropía reforzaba la noción del buen patrón cultivada por García Fernández, quien colaboró asiduamente con la Iglesia católica, participó de organizaciones de socorros mutuos y realizó numerosas donaciones benéficas en España y Buenos Aires.

El control del tiempo libre de los trabajadores fue otro de los pilares del proyecto paternalista. Con el propósito de revertir ciertos comportamientos como el consumo de alcohol y los juegos de azar, considerados expresiones del ocio y de la débil disciplina laboral, los industriales procuraron diseñar y regular las actividades recreativas de los obreros ${ }^{26}$. Entre los ámbitos de sociabilidad alentados por los empresarios bellavisteños debe subrayarse el Centro Obrero Tulio García Fernández fundado en la década de 1920. Esta entidad procuró liderar y controlar la organización mutualista local. Además, recuperó el tradicional aliento al mutualismo que caracterizó al mundo del trabajo provincial desde finales del siglo XIX, como una forma de promocionar la conciliación de clases y generar un "cordón sanitario" que evitara la difusión del socialismo y el anarquismo entre los obreros ${ }^{27}$. Este Centro se solventó con los aportes mensuales de los socios, a quienes proveyó de diferentes tipos de socorro en caso de accidentes laborales, de enfermedad o de muerte. Al ofrecer un paliativo ante tales contingencias, esta asociación buscó complementar las prestaciones brindadas por el ingenio, lo que contribuyó al bienestar de los afiliados y sus familias. Impulsado por los empresarios, pero administrado por los trabajadores del establecimiento, el Centro configuró un espacio de vinculación y ayuda mutua que cooperó a gestar formas de

\footnotetext{
${ }^{23}$ Bravo, María Celia. "Liberales, socialistas, Iglesia y patrones frente a la cuestión de los trabajadores en Tucumán”, en Suriano, Juan, et al. La cuestión social en Argentina, 1870/1943 (Buenos Aires: La Colmena, 2000), p. 45.

${ }^{24}$ Ibid., p. 42.

${ }^{25}$ Sobre las características del patrocinio patronal: Castel, Robert. La metamorfosis de la cuestión social (Buenos Aires: Paidós, 1997).

${ }^{26}$ Campi, Daniel. "Contrastes cotidianos. Los ingenios del norte argentino como complejos socioculturales, 1870-1930”, en Varia Historia... Op. Cit., p. 250.

${ }^{27}$ Bravo, María Celia y Teitelbaum, Vanesa. "Socialistas y católicos disputando el mundo de los trabajadores. Protesta, sociabilidad y política en Tucumán (1895-1910)”, en Entrepasados. Revista de Historia, n. ${ }^{\circ} 35$, Buenos Aires, 2009, p. 67.
} 
solidaridad y reciprocidad obrera que modelaron la experiencia de clase bellavisteña. Las jerarquías propias del entramado social azucarero delimitaron los ámbitos de sociabilidad y las actividades recreativas impulsadas desde el ingenio. Al margen de los espacios previamente mencionados, el principal ámbito de sociabilidad de las familias acomodadas de la comunidad bellavisteña (empleados jerárquicos y obreros calificados del ingenio, comerciantes y funcionarios) era el Club Social de Empleados y Obreros fundado en 1914. Se trataba de un espacio de reunión cotidiano destinado a actividades recreativas, como las cartas o el billar, en el que también se realizaban obras de teatro, bailes y eventos sociales de diferente índole. Estos ámbitos se convivieron; junto con otros dotados de mayor porosidad, tales como los clubes de deportes y juegos (fútbol, básquet, bochas, palitroque), en una matriz excluyente. Dichas actividades fueron alentadas por los industriales mediante donaciones de tierras y contribuciones monetarias, ayudas que se complementaban con descuentos aplicados al salario de los trabajadores.

Aunque los clubes no escaparon al modelo jerárquico del entramado social azucarero, al ser presididos por los propietarios o por los administradores, en algunas de sus prácticas ubicaron en un plano de cierta uniformidad a diferentes actores de la comunidad. Tal fue el caso del fútbol, deporte cuya popularidad en el mundo agroindustrial tucumano lo erigió como la principal actividad de los clubes deportivos. Numerosos ingenios formaron equipos como una vía para promover hábitos saludables, fortalecer la identidad comunitaria y galvanizar el sentimiento de pertenencia de sus trabajadores ${ }^{28}$. En el caso aquí analizado, las entidades auspiciadas por el ingenio asumieron denominaciones que homenajeaban a la familia propietaria, tales como los clubes Manuel García Fernández y Tulio García Fernández, o una alusión genérica sustentada en la pertenencia local, como el caso del Sportivo Bella Vista fundado en 1925 tras la fusión de los mencionados. En sus planteles se entremezclaron obreros, empleados y jugadores contratados por el establecimiento, impronta policlasista refrendada con la asistencia masiva a sus presentaciones ${ }^{29}$.

La política del buen patrón se combinó con prácticas coactivas tales como la proveeduría y el sistema de vales. El almacén de ramos generales "La Atalaya" fundado en 1898, era administrado por un concesionario designado por la empresa, que recibía los vales que el ingenio entregaba a los trabajadores como parte de pago $^{30}$. Se trataba de una modalidad que, al privar a los trabajadores del cobro total del salario en metálico, los ubicó en un lugar de dependencia y vulnerabilidad signado, en muchos casos, por prácticas abusivas. Merced a las protestas obreras y a los intentos de legislación emprendidos desde el Estado provincial, la centralidad de esta instancia de consumo popular fue revirtiéndose durante las primeras décadas del siglo XX hasta afianzar el cobro en efectivo. Sin embargo, este proceso lento y complejo no logró desterrar las proveedurías y el sistema de vales, los cuales pervivieron ilegalmente hasta la década

\footnotetext{
${ }^{28}$ Landaburu, Alejandra. Los empresarios... Op. Cit., p. 21.

${ }^{29}$ Valeros, Manuel y Salazar, Antonio. Notas sobre la historia ... Op. Cit., p. 335.

${ }^{30}$ Ibid., p. 54.
} 
de $1940^{31}$. Tal fue el caso del Bella Vista, cuya proveeduría siguió existiendo hasta la llegada del peronismo, en convivencia con locales comerciales ajenos a la influencia de la fábrica ${ }^{32}$.

En este sistema que alternaba paternalismo y coacción, las protestas y las formas de organización obrera fueron débiles e intermitentes. Esta tendencia, característica del mundo azucarero tucumano ${ }^{33}$, encontró en Bella Vista un ejemplo contundente. Los episodios de resistencia abierta que pudimos detectar hasta la irrupción del peronismo fueron escasos. Entre esos se destacaron los de julio de 1917 -en ocasión del cuestionamiento a la entrega de vales como parte del salario- y los de junio de 1919 -en reclamo por el aumento del estipendio y cumplimiento de la jornada laboral de 8 horas ${ }^{34}$. Sin embargo, estas protestas no lograron cristalizarse en paros. Por su parte, las coyunturas de conflictividad obrera encarnadas en las huelgas de 1904 y 1923 no tuvieron un impacto relevante en Bella Vista ${ }^{35}$. Tampoco repercutió en la localidad el proceso de creación de sindicatos de filiación socialista o comunista visible en algunos ingenios de Tucumán durante la década de $1930^{36}$.

Las modalidades que asumió esta mixtura entre paternalismo y coacción a la hora de desalentar prácticas sindicales pueden observarse en el intercambio epistolar entablado, con motivo de la protesta de 1919, entre Manuel García Fernández y su hijo mayor. En las misivas, Manuel (hijo) alertaba acerca del creciente clima de descontento entre los trabajadores y los intentos de fundar un gremio. La coyuntura no era casual. Por entonces existían fuertes tensiones entre la patronal azucarera y el gobierno radical a causa de los ensayos de intervención del Departamento Nacional del Trabajo en los

\footnotetext{
${ }^{31}$ La obligación patronal de pagar la totalidad del salario en metálico fue instaurada en 1904 mediante un arbitraje del gobernador Lucas Córdoba en respuesta a un conflicto obrero-industrial. En 1923, durante la gestión de Octaviano Vera, un nuevo ciclo de conflictividad obrera llevó a la Legislatura a promulgar la ley de salario mínimo que ratificó dicha obligación. Sin embargo, la resistencia de un sector de los industriales a acatar dicha disposición y el carácter prescindente de los gobiernos provinciales para combatir el sistema de vales permitieron su continuidad. Bravo, María Celia. Campesinos, azúcar y política: cañeros, acción corporativa y vida política en Tucumán (1895-1930) (Rosario: Prohistoria, 2008), p. 257.

32 Entrevista a Calixto, Vázquez, Bella Vista, enero 29 de 2015. Realizada por Florencia Gutiérrez y Leandro Lichtmajer.

${ }_{33}$ Desde los orígenes de la industria los trabajadores azucareros forjaron una tradición de resistencia que desafió el sistema laboral implementado por la élite mediante acciones en pequeña escala (tales como las fugas y motines de los peones). Campi, Daniel. "Captación forzada de mano de obra y trabajo asalariado en Tucumán, 1856-1896”, en Anuario Instituto de Estudios Históricos y Sociales, n. ${ }^{\circ}$ 8, Tandil, Universidad Nacional de Centro de la Provincia de Buenos Aires, pp. 47-71. Sin embargo, la conformación de experiencias asociativas duraderas encontró fuertes dificultades hasta la irrupción del peronismo. Fernández de Ullivarri, María. "Sindicatos en la capital del azúcar. Organización y lucha en el mundo del trabajo de la provincia de Tucumán (Argentina). 1930-1943”, en Historia Agraria. Revista de agricultura e Historia rural, n. ${ }^{\circ}$ 55, Murcia, Universidad de Murcia, 2011, pp. 105-137.

34 "En el ingenio Bella Vista. Conato de huelga", El Orden, Tucumán, julio 10 de 1917; Landaburu, Alejandra. "Los industriales y el Departamento Provincial del Trabajo ante el conflicto obrero de 1919 en Tucumán”, en Lobato, Mirta y Suriano, Juan. La sociedad... Op. Cit., pp. 85-104.

${ }^{35}$ Bravo, María Celia. Campesinos... Op. Cit.

${ }^{36}$ Fernández de Ullivarri, María. "Sindicatos en la capital del azúcar. Organización y lucha en el mundo del trabajo de la provincia de Tucumán (Argentina). 1930-1943”, en Historia Agraria ... Op. Cit., p. 116.
} 
La comunidad laboral del ingenio Bella Vista: la resignificación de la experiencia obrera...

conflictos obreros y su embrionario aliento a la organización sindical y a la mediación estatal como vías para promover la conciliación entre el capital y el trabajo ${ }^{37}$.

Los atisbos de organización laboral que emprendieron en 1919 algunos trabajadores bellavisteños provocaron una fuerte reacción de la patronal, quien se opuso tenazmente. Una primera medida intimidatoria fue el despido injustificado de los activistas. Como narró García Fernández a su padre:

[...] sabemos que abrieron en el Juzgado de Paz un registro para que se inscriban todos los peones que quieran formar parte de la sociedad [...] a uno ya se lo despidió sin darles explicaciones de porqué. Y a los otros cuatro se los prevendría [sic] de que serán despedidos si forman parte ${ }^{38}$.

Paralelamente, los patrones organizaron una policía privada del ingenio para amedrentar a los activistas. Estos mecanismos coactivos se complementaron con estrategias de cooptación, las cuales estuvieron destinadas principalmente a los trabajadores que lideraban el movimiento. En tal sentido, García Fernández le escribió a su hijo: “[...] debes procurar que todos los que hacen cabeza se conviertan en seguidores del ingenio. Es cuestión de dinero y de saberlo ofrecer". Pero el temor a no poder neutralizar el descontento ni frenar la declaración de la huelga, llevó a Los García Fernández a barajar la posibilidad de suspender las raciones alimentarias que proporcionaban a los obreros: “[...] si, cosa no probable, tenemos que suspender la molienda por huelga deberíamos cerrar tres o cuatro días la fábrica y no darles de comer". Cuando el conflicto alcanzó su cenit y un grupo de obreros se presentó con un pliego de condiciones ante García Fernández (hijo), este los despidió sin mediar explicaciones, decisión que desarticuló la protesta y aseguró la continuidad de la molienda ${ }^{39}$.

Aunque la huelga no llegó a consumarse, los despidos y la posibilidad de suspender las raciones alimentarias, lo que puso en riesgo la supervivencia obrera, evidenciaban hasta dónde era capaz de llegar la patronal para mantener sus prerrogativas en materia de fijación de salarios y extensión de la jornada laboral. Además de cercenar cualquier atisbo de práctica sindical, la cerril defensa de las atribuciones de los propietarios se encaminó por un doble objetivo: el de visibilizar el malestar empresarial frente a los intentos del gobierno de regular las relaciones entre el capital y el trabajo y el de "[...] demostrar a los obreros que somos más fuertes que ellos" ${ }^{40}$. De ese modo, los empresarios articularon un entramado de relaciones que, al combinar coacción

\footnotetext{
${ }^{37}$ La Unión Cívica Radical, partido fundado en 1891, accedió a la presidencia de la nación en 1916 de la mano de Hipólito Yrigoyen. Sobre la política del gobierno radical frente a los conflictos entre el capital y el trabajo: Lobato, Mirta y Suriano, Juan. La sociedad... Op. Cit.

${ }^{38}$ Archivo del Centro Cultural Alberto Rougés (ACCAR) (Tucumán), correspondencia de Manuel García Fernández (hijo), carta de Manuel García Fernández (hijo) a su padre, Bella Vista, mayo 21 de 1919, f. 1. Este material nos fue gentilmente cedido por Alejandra Landaburu.

${ }^{39}$ ACCAR (Tucumán), correspondencia de Manuel García Fernández (hijo), carta de Manuel García Fernández (hijo) a su padre, f. 1 (Bella Vista, junio 4 de 1919).

${ }^{40}$ Ibid.
} 
y paternalismo, desalentó la organización obrera. Sin embargo, los vínculos y las solidaridades gestados a lo largo del proceso de proletarización y alimentados a través del fútbol, la ayuda mutua y las formas de sociabilidad informal configuraron la experiencia obrera que se proyectó y se recuperó, de distintas formas, con la irrupción del peronismo.

Como veremos a continuación, este universo privado y paternalista fue jaqueado por el golpe de Estado de 1943. El decidido apoyo a la formación de sindicatos de base y el afianzamiento de la presencia tutelar del Estado resignificaron el universo obrero y cuestionaron "[...] supuestos concernientes a las relaciones sociales, las formas de deferencia y los acuerdos, en gran medida tácitos, acerca de cuál era el orden natural de las cosas y el sentido de los límites"41.

\section{La fundación del Sindicato Obrero del Ingenio Bella Vista y el desafío a la patronal}

A principios de la década de 1940, la experiencia de las comunidades azucareras fue resignificada por la sindicalización alentada por las agencias estatales y, al unísono, este proceso fue alimentado por las tradiciones y las trayectorias de la clase trabajadora agroindustrial. El golpe de Estado de 1943 y la llegada de Juan Domingo Perón al Departamento Nacional de Trabajo (luego convertido en STyP) en octubre de ese año, fueron claves en la promoción de la organización laboral. Para Perón, la intervención estatal y su rol mediador entre el capital y el trabajo eran el mejor reaseguro contra la agudización de la lucha de clases que amenazaba con horadar el tejido social. La organización sindical, promovida desde el Estado, se inscribió en esta preocupación.

En lo que respecta al universo azucarero, la Delegación Regional de la Secretaría de Trabajo y Previsión (DRSTyP) promovió la fundación de sindicatos de base en la veintena de ingenios que configuraban el complejo agroindustrial tucumano. Al igual que lo sucedido en otras fábricas, a fines de enero de 1944 un centenar de obreros del Bella Vista evadieron la mirada de la patronal para organizar en un local alejado de la fábrica una reunión, con el objetivo de fundar su propio sindicato. El 8 de junio de ese año estas células confluyeron en la creación de la Federación Obrera Tucumana de la Industria Azucarera (FOTIA), la organización sindical de mayor gravitación en el noroeste argentino durante el primer peronismo.

El movimiento asociativo comenzó en los ingenios para luego propagarse por los cañaverales, trayectoria organizacional que se replicó por la geografía azucarera. En efecto, un común denominador del armado sindical fue el liderazgo ejercido por los obreros de fábrica, especialmente, los más calificados. Manuel Parés, segundo jefe mecánico del ingenio Mercedes y referente en la fundación de la FOTIA, señaló que todos los sindicatos procuraron incorporar a trabajadores cualificados:

${ }^{41}$ James, Daniel. Resistencia e integración... Op. Cit., p. 46. 
El que no era herrero, era tornero, era segundo jefe, jefe mecánico, etc. [...] ¿Sabe por qué los patrones no se oponían del todo? Porque comenzaron los operarios especializados, que a los ingenios les hacía mucha falta. Pensaron que no les iban a hacer mucha contra porque, al fin y al cabo, eran los que estaban bien en el ingenio, no dejaban de trabajar nunca, siempre estaban ganando los sueldos ${ }^{42}$.

La condición de obrero calificado, refrendada con la permanencia laboral y la asignación de una vivienda, los posicionaba en un lugar de relevancia en la cadena productiva para reforzar el vínculo contractual con los empresarios. El sindicato del Bella Vista no escapó a este patrón organizacional. Sus primeras comisiones directivas se formaron con representantes de las escalas laborales más altas ${ }^{43}$.

Como señalamos, la dinámica del movimiento asociacionista comenzó en las fábricas y de allí se irradió a los surcos. Una vez constituido, el sindicato obrero bellavisteño eligió un delegado general para las colonias e incentivó la elección de un representante en cada una de ellas. Así, se intensificaron las acciones destinadas a sumar a ese importante contingente agrícola, la más numerosa y postergada asociación del mundo azucarero $^{44}$. La nutrida presencia de este segmento laboral fue un capital disputado por la dirigencia, en tanto su apoyo fue decisivo en las contiendas electorales y en la consolidación de liderazgos sindicales. La expansión territorial del sindicato de Bella Vista sintetiza la configuración de este campo de fuerzas. En la elección de la comisión directiva de mayo de 1945 participaron 313 socios, mientras que la llevada a cabo dos meses más tarde reportó 1.691 votantes, incremento sustentado en la incorporación de los trabajadores agrícolas. En ese marco, el itinerario y la consolidación de Felipe B. Sosa, uno de los más destacados referentes gremiales bellavisteños, expresó un reiterado derrotero sindical. Por un lado, su condición de guardia mecánico lo posicionó en un lugar relevante en el despunte y armado de la organización del sindicato y en su participación como tesorero de la FOTIA. Por otro, la adhesión alcanzada entre los peladores de caña explica su presencia en la segunda comisión directiva, así como su intervención en las pujas políticas del Partido Laborista y luego del Partido Peronista ${ }^{45}$.

\footnotetext{
${ }^{42}$ Entrevista a Manuel, Parés, Tucumán, diciembre de 1991. Realizada por María Celia Bravo y Pedro González. Extraída de Gutiérrez, Florencia y Rubinstein, Gustavo. El primer peronismo en Tucumán. Avances y nuevas perspectivas (Tucumán: Editorial de la Universidad Nacional de Tucumán, 2012), p. 314.

${ }^{43}$ Formaron la primera comisión directiva (diciembre de 1944): José Leguizamón (mecánico), Juan Lucas Coronel (albañil), Martín Juárez (mecánico), Juan de Boeck (sopletero mecánico), Juan Quesada (jefe de mecánicos) y Salvador Oviedo (oficial sopletero). La siguiente comisión directiva (mayo de 1945) estuvo conformada por Luis Navarro (oficial electricista), Andrés Paliza (encargado de los filtros), Estratón Gómez (electricista), Electo Lencinas (sin datos), Felipe B. Sosa (guardia mecánico), Antonio Salas (sin datos). Libro de Actas del Sindicato de Obreros del Ingenio Bella Vista (1944-1947), Acta n. ${ }^{15}$, junio 17 de 1945, p. 36 y Acta n. ${ }^{\circ}$ 20, diciembre 24 de 1944, p. 48. Entrevista a Calixto Vázquez, Bella Vista, enero 29 de 2015. Realizada por Florencia Gutiérrez y Leandro Lichtmajer.

${ }^{44}$ Rafael Desantis, obrero del ingenio Mercedes, señaló que la base de sustento de la dirigencia sindical "[...] era toda una masa que empujaba para el mismo lado, muy en especial los obreros de surco, que ese era el más explotado. Entonces ese ha sido el más unido". Entrevista a Rafael, Desantis, Tucumán, noviembre 3 de 1988. Realizada por Fernando Siviero. Extraída de Gutiérrez, Florencia y Rubinstein, Gustavo. El primer... Op. Cit., p. 354.

${ }^{45}$ Gutiérrez, Florencia y Lichtmajer, Leandro Ary. "Apuntes para una microhistoria del mundo azucarero
} 
Uno de los desafíos nodales de la dirigencia sindical de cara a las prerrogativas de la patronal fue la implementación del escalafón que surge al recuperar una demanda difundida entre las bases obreras: en enero de 1945 el decreto presidencial n. ${ }^{\circ} 678$ estableció el reconocimiento de 112 categorías socio-ocupacionales (62 oficios de fábrica y 50 tareas de surco $)^{46}$. Este desglose de clasificaciones se convirtió en un recurso clave para disminuir la facultad de los industriales en términos de contratación, despido o ascenso del personal. La dirigencia capitalizó este reconocimiento y desató una intensa puja con la patronal con el propósito de asignar oficios y recategorizar a los obreros, cuyos ascensos no solo implicaban mejoras salariales, sino el acceso a determinados derechos ${ }^{47}$.

A un mes de la promulgación del decreto el secretario del sindicato bellavisteño difundió las clasificaciones obreras y la negativa de la administración a " [...] reconocer en sus oficios a los compañeros Simón Olmos, como sopletero eléctrico [...] José Barrionuevo como sopletero autógeno y los que hacen el trabajo de talabartería"48. Estas demandas se agudizaron a lo largo de la década del cuarenta, a medida que ciertos oficios se convirtieron en el puente para acceder a derechos laborales (salario familiar, aguinaldo y reconocimiento de la antigüedad). Las pujas y las demandas se recrudecieron y el sindicalismo avanzó en una esfera de prerrogativas reservada exclusivamente a la patronal.

La respuesta de los empresarios no se hizo esperar: señalaron que el escalafón complicaba la definición de las actividades productivas, en tanto perturbaba la "[...] equitativa ubicación del trabajador por la dificultad muchas veces del adecuado deslinde [...] con el consiguiente aumento del salario [...]" y de los

durante el primer peronismo. El sindicato de obreros del ingenio Bella Vista (Tucumán, 1944-1949)", ponencia presentada en el Cuarto Congreso de Estudios sobre el Peronismo 1943-2014, Universidad Nacional de Tucumán, septiembre de 2014. El Partido Laborista fue creado en octubre de 1945 con el objeto de apoyar la candidatura presidencial de Juan Domingo Perón en los comicios de febrero de 1946. Fue disuelto en mayo de ese año al formarse el Partido Peronista (inicialmente denominado Partido Único de la Revolución Nacional), organización que pervivió hasta el golpe de Estado de 1955.

${ }^{46}$ La Industria Azucarera, Tucumán, n. ${ }^{\circ}$ 627, enero de 1946, pp. 2-3. El decreto citado reguló la actividad azucarera involucrando profundamente al Estado Nacional en el funcionamiento agroindustrial. La proyección de una Junta Nacional del Azúcar, destinada a regir de manera integral la actividad, y la creación de un Fondo Especial de Compensación y Asistencia Social, que reconocía a industriales y cañeros los mayores costos productivos y los derivados de la política social, revelaban un giro sustancial en la política azucarera. El gobierno peronista asumió este diseño institucional. Entre 1946 y 1949, la ampliación de los beneficios sociales y el incremento de las obligaciones anuales agudizaron la puja distributiva y demandaron un mayor involucramiento estatal. Finalmente, en 1949 la crisis de la balanza de pagos clausuró un ciclo de prosperidad y desnudó las dificultades del Estado para afrontar el peso de los subsidios y compensaciones.

${ }^{47}$ El escalafón otorgaba una pauta predecible de ascenso que cercenaba la libertad de los industriales frente a una eventual vacante, en tanto los obligaba a privilegiar el ascenso del trabajador que ocupaba la categoría inmediatamente inferior. Por otro lado, el obrero que era asignado en una categoría superior, para cubrir una vacante, tenía derecho a percibir el salario de esa calificación y debía ser reasignado en un plazo no mayor de dos meses; si la transferencia era a un nivel inferior el salario no podía disminuirse. Doyon, Louise. Perón... Op. Cit., p. 287.

${ }^{48}$ Libro de Actas del Sindicato de Obreros del Ingenio Bella Vista (1944-1947), Acta n. ${ }^{\circ}$ 16, febrero 15 de 1945, p. 37. 
costos productivos ${ }^{49}$. También denunciaron que la maraña de oficios y actividades discriminadas en las planillas era capitalizada por los sindicatos para avanzar sobre sus excluyentes facultades de contratación, despido o promoción de la mano de obra.

\section{El avance del poder obrero y la impugnación a la trama paternalista}

Tal como fue analizado, la trama del paternalismo bellavisteño contemplaba el funcionamiento de una olla popular, práctica que García Fernández promocionaba como expresión de la asistencia social brindada en su ingenio. En junio de 1945 el presidente del sindicato se preguntaba por qué el patrón “[...] tiene que decir que da de comer a los hijos de sus obreros [...] nosotros necesitamos trabajo y no [sic] olla popular" 50 . En una rama industrial, cuya mano de obra era mayoritariamente masculina, esta interpelación ponía en locución la ideología del varón proveedor. La olla popular era la expresión de una necesidad familiar insatisfecha, el incumplimiento de una obligación paternal subsanada por la filantropía patronal. Tanto esta como otras prácticas coactivas (vales de proveeduría, Gota de Leche, cocina infantil) reforzaban el supuesto de que la supervivencia "[...] dependía más de la buena voluntad del patrón que de la obligación contractual" ${ }^{\prime}$. Por tanto, su cuestionamiento apelaba a revertir el paternalismo empresarial y, a partir del trabajo, relegitimar al obrero en su condición de padre y sostén familiar.

La asistencia médica, otra de las expresiones que asumió la política del buen patrón, también fue cuestionada. Las denuncias se orientaron a la deficiencia del servicio de salud, en tanto el ingenio solo disponía de un médico que no salía a domicilio, motivo que en 1945 llevó al sindicato a solicitar la destitución del Dr. Juan A. Serra por no querer "[...] ir a atender" a la madre de un trabajador ${ }^{52}$. Las desavenencias con el médico del establecimiento fueron una constante. En 1948 los obreros reiteraron su pedido de traslado o cesantía debido a "[...] la falta absoluta de atención para con los pacientes" y denunciaron la carencia de comodidades y elementos imprescindibles para la atención médica ${ }^{53}$. Esta demanda, como muchas otras vinculadas a la asistencia social, se inscribía en trayectorias de larga data. Sin embargo, la coyuntura habilitada por el peronismo reformuló los sentidos de lo justo, lo que a su vez alentó la visibilización de postergadas reivindicaciones. Amparados por la nueva organización sindical y el papel intervencionista del Estado, los trabajadores presionaron a los industriales para satisfacer sus pedidos. Por su parte, frente a las exigencias de despido

\footnotetext{
${ }^{49}$ Schleh, Emilio. Compilación legal sobre el azúcar, t. XIII (Buenos Aires: Imprenta Ferrari, 1947), p. 163.

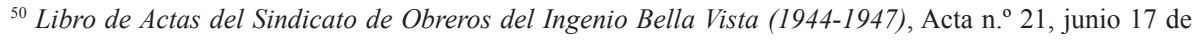
1945 , p. 53.

${ }^{51}$ Tinsman, Heidi. La tierra para el que la trabaja. Género, sexualidad y movimientos campesinos en la Reforma Agraria chilena (Santiago de Chile: LOM ediciones, 2009), p. 53.

${ }^{52}$ Libro de Actas del Sindicato de Obreros del Ingenio Bella Vista (1944-1947), Acta n. ${ }^{\circ}$ 14, diciembre 2 de 1944, p. 28 y Acta n. $^{\circ} 23$, septiembre 23 de 1945, p. 64.

53 “Obreros de Bella Vista piden la cesantía de un facultativo", Trópico, Tucumán, enero 24 de 1948. Esta demanda no fue atendida por la administración.
} 
o de reubicación del personal de confianza, los industriales subrayaron que no era admisible ni tolerable que "[...] la permanencia en sus puestos de los empleados en quienes los Ingenios han depositado su confianza, esté supeditada a la voluntad de los Sindicatos que se creen facultados para pedir su retiro, si la actuación de ellos no les satisface" 54 .

Simultáneamente, el sindicato apoyó la promulgación de la ley n. ${ }^{\circ} 2.018$ (enero de 1947), que establecía la asistencia médica gratuita y obligatoria en los ingenios a cargo de los industriales. Si bien se trataba de un aspecto atendido por el Bella Vista desde la fundación del hospital en 1916, la envergadura de la legislación suponía un salto cualitativo en términos de infraestructura y prestaciones ${ }^{55}$. La difusión y cumplimiento de la ley fue secundada por la dirigencia bellavisteña que lideró una intensa campaña entre los sindicatos del ingenio ${ }^{56}$. Este posicionamiento abrevaba en el supuesto de la responsabilidad empresarial en torno al cuidado de la salud obrera, obligación inescindible del carácter distributivo que debía asumir el proteccionismo azucarero. Las reivindicaciones de la dirigencia se apropiaron de esa histórica demanda, a la que dotaron de nuevos sentidos asociados al cuidado de la salud como derecho. De esta forma, los sindicatos apelaron a las nociones de lo justo que horadaron la noción de dádiva empresarial en favor de una nueva concepción de la salud.

En este contexto de preocupaciones, el poder disruptivo habilitado por el golpe de 1943 y continuado por el peronismo impulsó al sindicalismo a cuestionar diversas expresiones del paternalismo. Los dirigentes discutieron el descuento salarial aplicado por la patronal para el sostenimiento y uso del Club Sportivo Bella Vista e informaron que los obreros podían renunciar como socios de la institución. Al unísono, ciertos espacios de sociabilidad históricamente impulsados por los industriales intentaron preservarse, aunque escindidos del control empresarial. El mutualismo fue recuperado y convivió con la novel formación sindical. En mayo de 1944, el sindicato impulsó la creación de la Caja Mutual de Ayuda Recíproca que empezó a funcionar rápidamente gracias al fuerte apoyo brindado por aquel ${ }^{57}$. En efecto, la comisión directiva dispuso el pago obligatorio de la cuota mutual a todos sus socios, cobijó a la institución en la sede sindical y alentó actividades tendientes a fortalecerla (kermés, donación

\footnotetext{
54 “Las exigencias de los obreros de ingenios de Tucumán”, La Industria Azucarera, Tucumán, n. ${ }^{\circ}$ 650, diciembre de 1947, p. 595.

${ }^{55}$ La Ley hacía recaer en los industriales la totalidad de los costos de la construcción, el funcionamiento y el pago de salarios vinculados a la asistencia médica en los ingenios. El primer aspecto que atendía era la contratación de un médico jefe y un médico sub-jefe full time, quienes residirían en el pueblo azucarero y serían acompañados por un número variable de auxiliares (odontólogos y laboratoristas, parteras, enfermeros, visitadora de higiene, visitadora de ojos y farmacéutico). El servicio hospitalario debía incluir consultorios, sala de curaciones, laboratorios de rayos $\mathrm{X}$, farmacia, servicio de cirugía, de odontología y de obstetricia para la atención de los enfermos. Gutiérrez, Florencia y Rosales, María del Carmen. "La asistencia médica en los ingenios durante el primer peronismo: la resignificación de un viejo debate social", en Andes, n. ${ }^{\circ}$ 26, Salta, CEPIHA, 2015, en prensa.

${ }^{56}$ Entrevista a Rolando, González, Bella Vista, octubre 30 de 1999. Realizada por Atilio Santillán (h).

${ }^{57}$ Libro de Actas del Sindicato de Obreros del Ingenio Bella Vista (1944-1947), Acta n. ${ }^{\circ} 11$, mayo 30 de 1944, p. 17.
} 
de mobiliario $)^{58}$. La creación de la Caja Mutual eclipsó progresivamente al Centro Obrero Tulio García Fernández, reafirmando el avance del poder obrero en desmedro de las entidades promovidas por la patronal. Con sus prerrogativas desdibujadas, el Centro desapareció definitivamente a comienzos de la década de 1950.

Asimismo, la gravitación de la tradición mutualista en el nuevo ámbito asociacionista se expresó en términos simbólicos. El sindicato recuperó e hizo propio el emblema de la ayuda mutua (dos manos estrechándose) e impulsó ciertas prácticas asociadas a su ideario como la formación de una biblioteca y una banda de música. La coexistencia de estas formas asociativas revela la compleja trama azucarera de los cuarenta: la gravitación de las experiencias previas y las oscilantes respuestas obreras inscritas entre el cuestionamiento y la resignificación.

La interpelación al paternalismo se combinó con el desafío a tradicionales prerrogativas industriales. En ese marco, la fundación del sindicato obrero de Bella Vista supuso el avance del poder obrero. Los trabajadores cuestionaron la autoridad de Los García Fernández e impulsaron una transferencia de atribuciones vinculadas al control de los procesos productivos y a la administración y organización de la fuerza laboral, prerrogativas que hasta ese momento eran excluyentes de la patronal. La huelga declarada por el sindicato bellavisteño en julio de 1945 permite reflexionar sobre cómo la coyuntura de oportunidades habilitada por el golpe de Estado de 1943 promovió la transferencia de poder en los ingenios y su avance interpeló no solo a los industriales, sino al propio Estado. La experiencia del Bella Vista permite advertir qué contornos asumió la resignificación de los límites de lo posible en el ingenio y la manera en que las experiencias previas gravitaron en la tramitación de las demandas, situación que expresó el derrotero sindical escindido entre la protesta y la negociación.

El 17 de julio de 1945 el sindicato de Bella Vista declaró la huelga para reclamar el cumplimiento de la legislación laboral vigente -clasificaciones obreras, pago de vacaciones, horas extras y feriados-; la cesantía del médico del ingenio y de obreros no sindicalizados y la reincorporación de un grupo de cosedoras de bolsas de azúcar recientemente despedidas. Las demandas apelaban al cumplimiento de emergentes derechos laborales pero también avanzaban sobre tradicionales prerrogativas patronales, como el despido o la reincorporación del personal del ingenio y la clasificación de los obreros. Este último aspecto se tornó particularmente complejo con la implementación del escalafón, que implicó el reconocimiento de 112 categorías ocupacionales. Como señalamos, el desglose de clasificaciones se convirtió en un recurso clave para disminuir la facultad de los industriales en términos de contratación, despido o ascenso del personal. La medida de fuerza se declaró a solo un mes de la conformación de la comisión paritaria de reclamos y conciliación, constituida por el Poder Ejecutivo provincial y la dirigencia fotiana para encauzar orgánica y formalmente las reivindicaciones azucareras. De esta forma, la avanzada sindical cuestionó la autoridad empresarial en los ingenios pero también interpeló al Estado

\footnotetext{
${ }^{58}$ La imbricación entre ambas organizaciones se manifestó en la conformación de las comisiones directivas que compartían miembros de la dirigencia.
} 
y a la Federación, obligando a estos últimos a contener los desbordes de la ofensiva obrera y a fijar las fronteras y modalidades de las reivindicaciones ${ }^{59}$.

La huelga evidenció la construcción del poder obrero al compás del quiebre de las formas de deferencia al interior de las fábricas pero también interpeló las instancias de conciliación y negociación sectorial y confrontó a la dirigencia sindical con los límites de lo razonable. El abandono de las tareas por parte de los obreros bellavisteños (17 de julio) fue interpretado por las autoridades de la DRSTyP como "[...] un acto de sabotaje a la fábrica, ya que esta corría el peligro de que explotaran las calderas, lo que fue evitado por la intervención oportuna de otras personas que acudieron a impedir un posible daño" ${ }^{60}$. En consonancia, la agencia estatal declaró la ilegalidad del paro, decidió la intervención y clausura del sindicato e inhabilitó a los miembros de la comisión directiva para ejercer cargos sindicales por cinco años. Lejos de amedrentarse, los obreros continuaron con la medida de fuerza y desafiaron la sanción al subrayar su arbitrariedad y provocación ${ }^{61}$.

El día 20, previo acuerdo entre el administrador del ingenio, las autoridades de la FOTIA y la DRSTyP, la vuelta al trabajo habilitó el inicio de las negociaciones sectoriales. El 23 de julio la Delegación convocó a una asamblea para elegir a las autoridades del sindicato. Los socios reeligieron de forma unánime a la comisión directiva que había declarado la huelga. De ese modo, las elecciones pusieron en tensión el mundo laboral azucarero. La legitimación y respaldo a la dirigencia castigada por las autoridades confrontaba la sanción disciplinar de la agencia estatal y anunciaba una práctica que se tornaría en común denominador: el desborde de las bases y la conflictividad que escapaba a las instancias de arbitraje y negociación promovidas por la DRSTyP y la dirigencia fotiana ${ }^{62}$. Finalmente, la intermediación de la FOTIA logró el levantamiento de la inhabilitación, resolución que posibilitó la normalización del sindicato y el reconocimiento de sus autoridades.

A mediados de agosto, la patronal y el sindicato firmaron un convenio que recuperó las principales reivindicaciones de los huelguistas. Entre los puntos más destacados se reconocía el pago de feriados y de vacaciones para los obreros de las colonias; fijación de jornales a trabajadores de baja calificación; pago de horas extras y feriados al personal de fábrica; reincorporación de las cosedoras de bolsas de azúcar; mejoras en la vivienda obrera; consideración del pedido de dar preferencia a los trabajadores sindicalizados en caso de nuevas contrataciones y el establecimiento de clasificaciones obreras con su correlato salarial ${ }^{63}$.

\footnotetext{
${ }^{59}$ Gutiérrez, Florencia. "La irrupción del poder obrero en los ingenios azucareros: avances, límites y cuestionamientos. Tucumán, 1944-1955”, en Quinto Sol. Revista de historia regional, vol. XVIII, n. ${ }^{\circ} 2$, Santa Rosa, Instituto de Estudios Socio-Históricos, Universidad de La Pampa, 2014, pp. 1-23.

60 "Un paro de obreros del ingenio Bella Vista ha sido declarado ilegal”, La Gaceta, Tucumán, julio 18 de 1945 , p. 10.

${ }_{61}$ "Se mantiene la huelga del ingenio Bella Vista", La Gaceta, Tucumán, julio 19 de 1945, p. 8.

${ }^{62}$ Libro de Actas del Sindicato de Obreros del Ingenio Bella Vista (1944-1947), Acta n. ${ }^{\circ} 22$, julio 29 de 1945 , pp. 57-58.

63 "Celebróse [sic] un convenio de trabajo en Bella Vista”, La Gaceta, Tucumán, agosto 16 de 1945, p. 9.
} 
En síntesis, la huelga descubrió las implicancias del avance sindical en el ingenio Bella Vista. La presencia tutelar del Estado alentó la sindicalización, cuestionando la discrecionalidad del paternalismo empresarial y avanzando en el reconocimiento de derechos, muchos de ellos tradicionalmente resistidos por los industriales. Al valerse de la inédita "coyuntura de oportunidades", el sindicato cuestionó prácticas del buen patrón, resignificó y se apropió de otras, procurándolas escindir del control empresarial, y promovió una transferencia de poder que interpeló no sólo a los industriales, sino al propio Estado y a la dirigencia de la FOTIA. El desafío a los códigos de deferencia y la modificación del "sentido de los límites" alteró aquello que los trabajadores podían expresar, cuestionar y demandar ${ }^{64}$. Esta situación que socavó una relación construida a partir de un principio de fidelidad y reciprocidad, fue leída por la patronal en términos de ruptura de un pacto moral. Así lo expresó el administrador del ingenio al señalarle a uno de los miembros fundadores del sindicato que en lugar de ponerse en contra debían ser agradecidos, teniendo en cuenta que el Bella Vista siempre los había tratado bien $^{65}$. Esta lectura fue inescindible del menoscabo a las prerrogativas industriales, evidenciadas, como vimos, en el proceso abierto por el escalafón, la intervención del sindicato en la organización de los procesos laborales y la administración del personal. En este nuevo escenario, la patronal no pudo desconocer al sindicato como un nuevo factor de poder local, más bien tuvo que aprender a relacionarse con este, alternando una actitud defensiva con formas de negociación y consenso.

\section{Conclusión}

A principios de la década del cuarenta, el fortalecimiento del sindicalismo y la expansión de derechos alentados por el Estado transformaron sensiblemente el mundo laboral argentino. Este proceso, dinamizado y tensionado por la clase trabajadora, asumió particulares modulaciones a lo largo del país. Las condiciones laborales de las distintas ramas productivas, las trayectorias organizativas y de protesta obrera, las formas de sociabilidad, las tradiciones políticas de los trabajadores, entre otras, promovieron singulares dinámicas que necesitan ser recuperadas en su especificidad.

En el caso de la agroindustria azucarera, el estudio de este derrotero privilegió la vertiginosa expansión sindical sintetizada en la fundación de FOTIA y sus vínculos con el Partido Peronista. Este énfasis historiográfico permitió desentrañar las complejas relaciones entre sindicalismo y política, pero el paraguas de la condición azucarera y la identidad fotiana y peronista de los obreros solapó vivencias inherentes a su constitución como actores colectivos. En este contexto, el desafío de recuperar la multiplicidad de experiencias de clase nos interpeló a reducir la escala de observación y a hacer foco en la comunidad del ingenio Bella Vista.

En 1944, los obreros bellavisteños se apropiaron del impulso organizativo alentado por el Estado y formaron su primer sindicato. El aliento "desde arriba" fue resignificado por una comunidad que se reconocía en rutinas de explotación, en historias de luchas y en percepciones de lo injusto y que había fraguado formas de

\footnotetext{
${ }^{64}$ James, Daniel. Resistencia... Op. Cit., p. 46.

${ }^{65}$ Entrevista a Rolando, González, Bella Vista, octubre 30 de 1999. Realizada por Atilio Santillán (h).
} 
reciprocidad y solidaridad inescindibles del paternalismo articulado por Los García Fernández desde fines del siglo XIX. El avance sindical, respaldado por el Estado y modelado por las trayectorias de los trabajadores, habilitó formas desconocidas del poder obrero. La transferencia de autoridad operada en la fábrica, en detrimento de las prerrogativas empresariales, y la interpelación a la política del buen patrón expresaron el trastrocamiento de acuerdos, de formas y de límites inherentes al pueblo azucarero. Las fronteras y consensos tácitos que delimitaban lo que "los de abajo" podían expresar, demandar o discutir con los industriales se resquebrajaron y promovieron nuevas formas de interlocución.

Los trabajadores interpelaron tradicionales prácticas del paternalismo, como la olla popular y los aportes para el sostenimiento del Club Sportivo. Otras como el mutualismo, fueron recuperadas para escindirse del control patronal y promover una competencia de sociabilidades que finalmente eclipsó a la mutual creada por los propietarios. Al unísono, postergadas reivindicaciones como la asociada a la asistencia médica en los ingenios, lograron expresarse y horadar la noción de dádiva empresarial en favor de una nueva conceptualización en términos de derecho. Sin embargo, el avance obrero más disruptivo fue el vinculado con el control de los procesos productivos y la administración del personal, desafío que puso en cuestión la excluyente autoridad de la patronal. Estas demandas interpelaron a los industriales pero también a la dirigencia fotiana y a las agencias estatales, las cuales procuraron controlar y encauzar formal y orgánicamente este tipo de reivindicaciones. De esta forma, la redefinición del "sentido de los límites" conmocionó a la patronal bellavisteña y alertó al propio Estado que intentó controlar el desafiante poder obrero.

En síntesis, a principios de los cuarenta, los propietarios del Bella Vista asistieron al resquebrajamiento de un pacto moral sustentado durante décadas en estrategias de consenso y coacción. Por su parte, los obreros capitalizaron la favorable coyuntura habilitada por el peronismo para cuestionar el control paternalista y el poder empresarial, impugnaciones que implicaron un viraje en su experiencia de clase. A este proceso, signado por tangibles expresiones como la creación de una mutual, la exigencia de ascenso de un obrero o la conquista de un derecho, le fue inherente una transformación inmaterial que, imposible de cuantificar, resignificó el orgullo y la autoestima de los trabajadores y conmocionó al mundo patronal.

\section{Fuentes}

\section{Fuentes primarias}

\section{Archivos}

Archivo del Centro Cultural Alberto Rougés (ACCAR), correspondencia de Manuel García Fernández (hijo).

Archivo privado de Manuel Valeros (AMV), Libro de Actas del Sindicato de Obreros del Ingenio Bella Vista (1944-1947). 
La comunidad laboral del ingenio Bella Vista: la resignificación de la experiencia obrera...

\section{Publicaciones periódicas}

El Orden, Tucumán, 1917, 1919, 1943.

La Gaceta, Tucumán, 1943-1945.

La Industria Azucarera, Tucumán, 1943-1947.

La Nación, Buenos Aires, 1945.

Trópico, Tucumán, 1947-1948.

\section{Libros}

Centro Azucarero Argentino. Asistencia social en la industria azucarera. Buenos Aires: Establecimiento Gráfico Ferrari Hermanos, 1943.

Padilla, Vicente. El norte argentino. Historia política-administrativa, social, comercial e industrial de las provincias de Tucumán, Salta, Jujuy, Santiago del Estero y Catamarca. Buenos Aires: Establecimiento gráfico Ferrari Hermanos, 1922.

Schleh, Emilio. Compilación legal sobre el azúcar, t. XIII. Buenos Aires: Imprenta Ferrari, 1947.

\section{Entrevistas}

Entrevista a Calixto, Vázquez, Bella Vista, 2015.

Entrevista a Manuel, Parés, Tucumán, 1991.

Entrevista a Rafael, Desantis, Tucumán, 1988.

Entrevista a Rolando, González, Bella Vista, 1999.

\section{Fuentes secundarias}

\section{Libros}

Bravo, María Celia. Campesinos, azúcar y política: cañeros, acción corporativa y vida política en Tucumán (1895-1930). Rosario: Prohistoria, 2008.

Castel, Robert. La metamorfosis de la cuestión social. Buenos Aires: Paidós, 1997.

Doyon, Louise. Perón y los trabajadores. Los orígenes del sindicalismo peronista, 1943-1955. Buenos Aires: Siglo Ventiuno, 2006.

Garzón Rogé, Mariana. El peronismo en la primera hora. Mendoza: Editorial de la Universidad Nacional de Cuyo, 2014. 
Gutiérrez, Florencia y Rubinstein, Gustavo. El primer peronismo en Tucumán. Avances y nuevas perspectivas. Tucumán: Editorial de la Universidad Nacional de Tucumán, 2012.

James, Daniel. Resistencia e integración. El peronismo y la clase trabajadora argentina (1946-1976). Buenos Aires: Sudamericana, 1990.

Klubock, Thomas. Contested Communities. Class, Gender and Politics in Chile's El Teniente Cooper Mine, 1904-1951. Durham: Duke University Press, 1998.

Lobato, Mirta. La vida en las fábricas. Trabajo, protesta y política en una comunidad obrera, Berisso (1904-1970). Buenos Aires: Prometeo, 2004.

Lobato, Mirta y Suriano, Juan. La sociedad del trabajo. Las instituciones laborales en Argentina (1900-1955). Buenos Aires: Edhasa, 2014.

Macor, Darío y Tcach, César. La invención del peronismo en el interior del país. Santa Fe: Universidad Nacional del Litoral Editora, 2003.

Mercado, Lucía. El Gallo Negro. Vida, pasión y muerte de un ingenio azucarero. Tucumán: Producciones Gráficas, 1999.

Paterlini de Koch, Olga. Pueblos azucareros de Tucumán. Tucumán: Facultad de Arquitectura y Urbanismo, Universidad Nacional de Tucumán, 1987.

Rubinstein, Gustavo. Los sindicatos azucareros en los orígenes del peronismo tucumano. Tucumán: Universidad Nacional de Tucumán, 2006.

Tinsman, Heidi. La tierra para el que la trabaja. Género, sexualidad y movimientos campesinos en la Reforma Agraria chilena. Santiago de Chile: LOM ediciones, 2009.

Valeros, Manuel y Salazar, Antonio (comps.). Notas sobre la historia de Bella Vista. Tucumán: Universidad Nacional de Tucumán, 2012.

\section{Capítulos de libros}

Bravo, María Celia. "Liberales, socialistas, Iglesia y patrones frente a la cuestión de los trabajadores en Tucumán”, en Suriano, Juan (comp.), La cuestión social en Argentina, 1870/1943. Buenos Aires: La Colmena, 2000.

Campi, Daniel. "Economía y sociedad en las provincias del norte", en Lobato, Mirta (dir.), El progreso, la modernización y sus límites 1880-1916. Buenos Aires: Sudamericana, 2000.

Landaburu, Alejandra. "Los industriales y el Departamento Provincial del Trabajo ante el conflicto obrero de 1919 en Tucumán”, en Lobato, Mirta y Suriano, Juan. La sociedad del trabajo. Las instituciones laborales en Argentina (1900-1955). Buenos Aires: Edhasa, 2014. 
La comunidad laboral del ingenio Bella Vista: la resignificación de la experiencia obrera...

Negro, Antonio Luigi. "Zé Brasil foi ser peão. Sobre a dignidade do trabalhador não qualificado na fábrica automobilística", en Batalha, Claudio; Teixeira da Silva, Fernando y Fortes, Alexandre (orgs.), Culturas de Classes. Campinas: UNICAMP, 2009.

Thompson, Edward Palmer. "Folklore, antropología e historia social", en Thompson, Edward Palmer. Las peculiaridades de lo inglés y otros ensayos. Valencia: Centro Francisco Tomás y Valiente Universidad Nacional de Educación a Distancia AlziraValencia y Fundación Instituto de Historia Social, 2002.

\section{Artículos en revistas}

Bravo, María Celia y Teitelbaum, Vanesa. "Socialistas y católicos disputando el mundo de los trabajadores. Protesta, sociabilidad y política en Tucumán (1895-1910)”, en Entrepasados. Revista de Historia, n. ${ }^{\circ}$ 35, 2009.

Campi, Daniel. "Captación forzada de mano de obra y trabajo asalariado en Tucumán, 1856-1896”, en Anuario Instituto de Estudios Históricos y Sociales, n. ${ }^{\circ}$ 8, 1993.

Campi, Daniel. "Contrastes cotidianos. Los ingenios del norte argentino como complejos socioculturales, 1870-1930”, en Varia Historia, vol. XXV, n. ${ }^{\circ}$ 41, 2009.

Fernández de Ullivarri, María. "Sindicatos en la "capital del azúcar”. Organización y lucha en el mundo del trabajo de la provincia de Tucumán (Argentina). 1930-1943”, en Historia Agraria. Revista de agricultura e Historia rural, n. ${ }^{\circ}$ 55, 2011.

Gutiérrez, Florencia. "La irrupción del poder obrero en los ingenios azucareros: avances, límites y cuestionamientos. Tucumán, 1944-1955”, en Quinto Sol. Revista de historia regional, vol. XVIII, n. ${ }^{\circ}$ 2, 2014.

Gutiérrez, Florencia y Rosales, María del Carmen. "La asistencia médica en los ingenios durante el primer peronismo: la resignificación de un viejo debate social", en Andes, n. ${ }^{\circ}$ 26, 2015.

\section{Tesis}

Landaburu, Alejandra. Los empresarios azucareros y la cuestión social. Tucumán, 1904-1930, (Tesis doctoral), Universidad Nacional de Tucumán, 2014.

Moyano, Daniel. Firmas familiares, empresariado e industria azucarera en Tucumán, 1895-1945, (Tesis doctoral), Universidad Nacional de Tucumán, 2011.

\section{Ponencias en reuniones cientificas}

Gutiérrez, Florencia y Lichtmajer, Leandro. “Apuntes para una microhistoria del mundo azucarero durante el primer peronismo. El sindicato de obreros del ingenio Bella Vista (Tucumán, 1944-1949)", ponencia presentada en el Cuarto Congreso de Estudios Sobre el Peronismo 1943-2014, Universidad Nacional de Tucumán, septiembre de 2014. 